LIFE SCIENCES 
TABLE OF CONTENTS

VOLUME 43, NUMBER 19

ILONA VATHY and ANNE $M$. ETGEN

T.J. COLLINS, S. CHATTERJEE, L.S. LEGATE and T.K. BANERJI

E. GIRALDO, F. MARTOS, A. GOMEZ, A. GARCIA, M.A. VIGANO, H. LADINSKY and

F. SANCHEZ DE IAA CUESTA

AI,EXANDER L. GERBES, ANGELIKA M. VOLLMAR, YINING XIE and RAINER M. ARENDT

G. CARO, M. BARRIOS and J.M. BAEYENS

JAN G.C. VAN AMSTERDAM, KAREL J.H. VAN BUUREN, MARCO J. KRIELAART, OBBE P. ZUIDERVELD and ROB P.J.H. TIJMS

W. SUTANTO and E.R. DE KLOET

L. ALESSIO, S. GOVONI, G. SALAR, F. BATTAINI, R. IAVICOLI and $M$. TRABUCCHI

SAT BIR S. KHALSA and GENE D. BLOCK

HIROSHI SAITO, MITSUAKI NAKAMARU, TOSHIO OGIHARA, HIROMI RAKUGI, YUICHI KUMAHARA, TADASHI INAGAMI and KAZUAKI SHIMAMOTO i AIDS RESEARCH COMMUNICATIONS

1493 Ovarian Steroids and Hypothalamic Norepinephrine Release: Studies Using In Vivo Brain Microdialysis

1501 Lithium: Evidence for Reduction in Circulating Testosterone Levels in Mice Following Chronic Administration

1507 Characterization of Muscarinic Receptor Subtypes in Human Tissues

1517 Presence of the Atrial Natriuretic Factor (ANF) in Human Ascitic Fluid

1523 Dose-Dependent and Stereoselective Antagonism by Diltiazem of Naloxone-Precipitated Morphine Abstinence After Acute Morphine-Dependence In Vivo and In Vitro

1529 Effect of Inhibitors of Enkephalin Degradation in the Isolated Guinea-Pig Ileum

1537 ZK91587: A Novel Synthetic Antimineralocorticoid Displays High Affinity for Corticosterone (Type I) Receptors in the Rat Hippocampus

1545 Age-Related Changes of Methionine-Enkephalin and Beta-Endorphin / Beta-Lipotropin Immunoreactivity in Human CSF

1551 Phase-Shifts of the Bulla Ocular Circadian Pacemaker in the Presence of $\mathrm{Cal}-$ modulin Antagonists

1557 Effect of Vasodilator Prostaglandins on the Vascular Renin-Angiotensin System

INDEXED IN: Current Contents, CABS, BIOSIS Database, Index Medicus, MEDLINE, Psychol. Abstr., Nutr. Abstr., Energy Res. Abstr., Energy Data Base, Ophthal. Lit., Biological Abstr., Excerpta Medica, PASCAL-CNRS Database 
PETER R. OELTGEN, SITA

P. NILEKANI, PAULA A.

NUCHOLS, WILMA A. SPURRIER

and TSUNG-PING SU
1565 Further Studies on Opioids and Hibernation: Delta Opioid Receptor Ligand Selectivity Induced Hibernation in Summer-Active Ground Squirrels

I Software Survey Section 


\title{
PRESENCE OF THE ATRIAL NATRIURETIC FACTOR (ANF) IN HUMAN ASCITIC FLUID
}

\section{Alexander L. Gerbes, Angelika M. Vollmar , Yining Xie, and Rainer M. Arendt}

\begin{abstract}
Medizinische Klinik II and I, Klinikum Grosshadern and Institute of Pharmacology, Veterinary School, University of Munich, Munich, Federal Republic of Germany
\end{abstract}

(Received in final form September 12, 1988)

\section{Summary}

\begin{abstract}
Presence of atrial natriuretic factor (ANF)-like material was demonstrated by radioimmunoassay in ascitic fluid of 14 patients with cirrhosis of the liver. Immunoreactive ANF concentrations $(M+S E M)$ were $2.4+0.5$ $\mathrm{fmol} / \mathrm{ml}$ in ascites, significanily lower $(\mathrm{p}<0.001)$ than the corresponding plasina concentrations of $15.5+$ $2.6 \mathrm{fmol} / \mathrm{ml}$. High performance gel permeation chromato= graphy and reverse phase high performance chromatography of the ascitic ANF immunoreactivity showed correspondence to the alpha human ANF(99-126). ANF levels in ascites were significantly $(p<0.01)$ correlated to levels in plasma $(r=0.66)$.
\end{abstract}

In patients with cirrhosis of the liver and ascites the pathophysiological role of ANF has not been fully elucidated $(1,2)$. Following intravenous reinfusion of ascites elevated ANF plasma levels have been reported $(3,4,5)$. This might be due to ANF release stimulated by the hemodynamic changes following ascites infusion or due to elevated ANF concentrations in ascitic fluid. Whereas the presence of atrial natriuretic factor (ANF) has been demonstrated in various fluids of the human body, such as plasma (6), urine (7) and cerebrospinal fluid (8), ascitic fluid has not been examined as yet for the occurence of ANF. In this study the presence of ANF in ascitic fluid was investigated.

\section{Subjects and Methods}

Fourceen patients (11 men, 3 women, aged 42 to 81 years) with biopsy proven cirrhosis of the liver and ascites were investigated. 
Determination of ANF by radioimmunoassay. Simultaneously obtained samples of ascitic fluid and peripherat venous blood were drawn into pre-cooled syringes and immediately transferred to pre-cooled polystyrene tubes containing 500 kallikrein inhibitor units aprotinin per $\mathrm{ml}$ and $1 \mathrm{mg}$ sodium EDTA per ml. Samples were centrifuged at $4^{\circ} \mathrm{C}$, the supernatant was immediately frozen and stored at $-80^{\circ} \mathrm{C}$. Extraction of ascites aliquots as well as RIA procedures were performed in the same way as for plasma samples; procedures were modified from (6) and have been detailed elsewhere (9). Briefly, samples were extracted by adsorption to Amberlite XAD-2 adsorbent resin. The final titer of the C-terminal directed antibody Toni III was 1:120000, crossreactivity to rat-pro ANF was $48 \%$ and the assay sensitivity was 0.5 fmol alpha human ANF/iube. The $50 \%$ binding intercept of the standard curve was $10 \mathrm{fmol}$.

Chromatographic analysis of ANF immunoreactivity. Ascitic fluid extracts of 4 patients were subjected to high performance gel permeation chromatography (HPGPC) and reverse phase high performance chromatography (RP-HPC).

High performance gel permeation chromatography (HPGPC): Lyophilized ascitic fluid $(10 \mathrm{ml})$ was dissolved in $25 \mu 1$ column eluens and applied to a Spherogel TM TSK, 2000 SW column $(10 \mu \mathrm{m}, 7.5 \mathrm{~mm} x$ $300 \mathrm{~mm}$, Beckman Instruments, San Ramon, CA, USA), eluted with $0.09 \%$ trifluoroaceticacid (TFA) containing $0.005 \mathrm{M} \mathrm{Na} \mathrm{SO}_{4}, 0.002 \mathrm{M}$ $\mathrm{NaH}_{2} \mathrm{PO}_{4}$ and $30 \%$ acetonitrile (flowrate: $0.3 \mathrm{ml} / \mathrm{min}$ ). ${ }^{2} \mathrm{Ca}$ libration was carried out with bovine serum albumin (BSA) (V), vitamin BI2 $\left(V_{t}\right)$, rat pro-ANF $(2-126)$ and alpha human ANF (99-126). Immunoreactive ANF (IR-ANF) fractions (0.5ml), detected by RIA, were pooled and lyophilized.

Reverse phase high performance chromatography (RP-HPC): An aliquot of the pooled IR-ANF fractions of the HPGPC run was redissolved in $25 \mu 10.1 \%$ TFA and loaded on a HPLC C 18 ODS U1trasphere TM column $(5 \mu \mathrm{m}, 2 \mathrm{~mm} \times 150 \mathrm{~mm}$, Beckman Instruments, San Ramon, USA) according to $(10)$. Elution was carried out with a linear gradient of acetonitrile $(10-80 \%, 45 \mathrm{~min})$ in $0.1 \%$ TFA (flowrate: $0.2 \mathrm{ml} / \mathrm{min}$ ). Calibration of the column was performed with synihetic atriopeptin I and III, alpha human ANF (99-126) and rat pro-ANF (2-126). Fractions $(0.4 \mathrm{ml})$ were assayed for ANF immunoreactivity.

Statistical evaluation. Differences between ascitic and plasmatic ANF concentrations were compared by paired t-test; the Pearson correlation coefficient was decermined by the usual linear least squares test. Data are presented as mean and standard error $(M+S E M)$.

\section{Results}

\section{Radioimmunoassay}

Serial dilutions of ascites were parallel to the standard curve, as shown in figure 1. Recoveries of 7.8 and 15.6 fmol synthetic human alpha ANF added to samples of ascites and plasma prior to exiraction were $84 \%$ and $67 \%$ in ascites and $75 \%$ and $65 \%$ in piasma. Nonspecific binding, determined in the RIA without antiserum was less than 5\% in both ascites and plasma. Ascitic Aivf concentrations were $2.4+0.5 \mathrm{fmol} / \mathrm{ml}$, significantly $(p<0.001)$ lower than ANF concentrations in plasma $(15.5 \pm 2.6 \mathrm{fmol} / \mathrm{ml})$. ANF levels 
in ascites were significantly correlated to ANF plasma levels ( $r=$ $0.56, p<0.01$; figure 2).

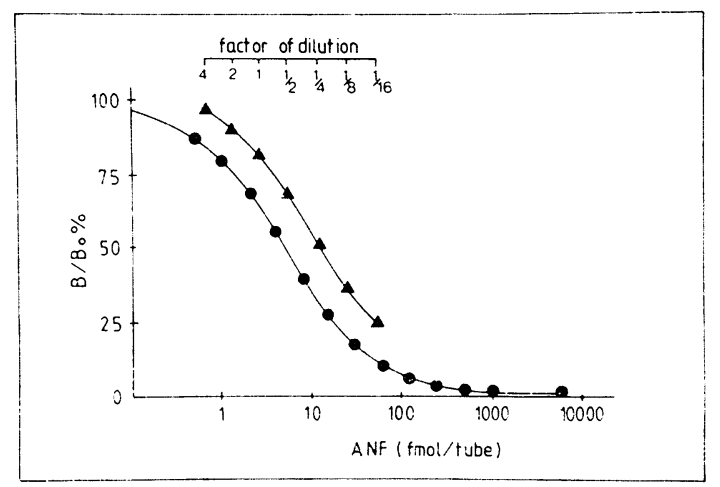

FIG. I

A standard curve for radioiminunoassay of alpha human ANF (circles) in comparison to serial dilutions of ascitic fluid (triangles). Each point is the mean of two experiments. Dilution curves parallel the standard curves.

FIG. 2

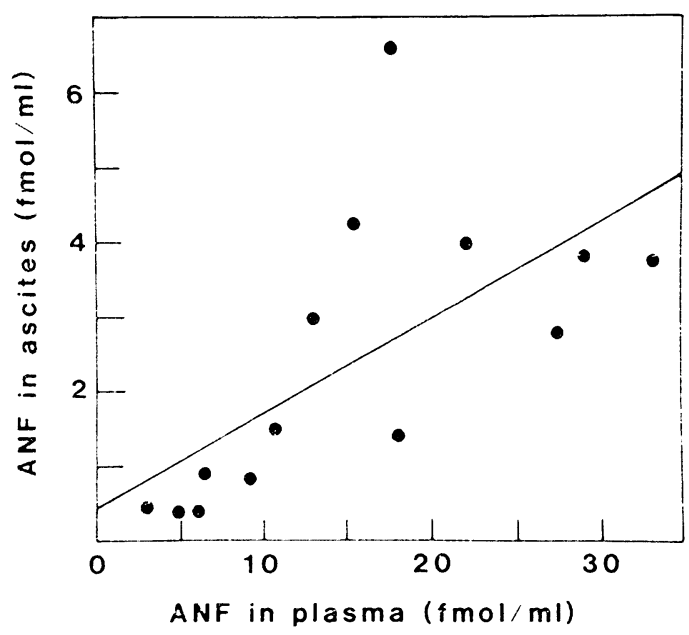

Significani correlaiton of ANF concentrations in ascites and in plasma of 14 patients with cirrhosis of the liver $(r=$ $0.56, p<0.011$.

\section{HPLC characterization of immunoreactive ANF}

When pre-extracted ascitic fluid was chromatographed on HPGPC and reverse phase HPLC, immunoreaciive ANF was detected as a single peak coeluting with synthetic alpha human ANF. No significant anounts of nigher molecular weight ANF-like material such as precursor pro-ANF was detected, as demonstrated in figure 3 . 

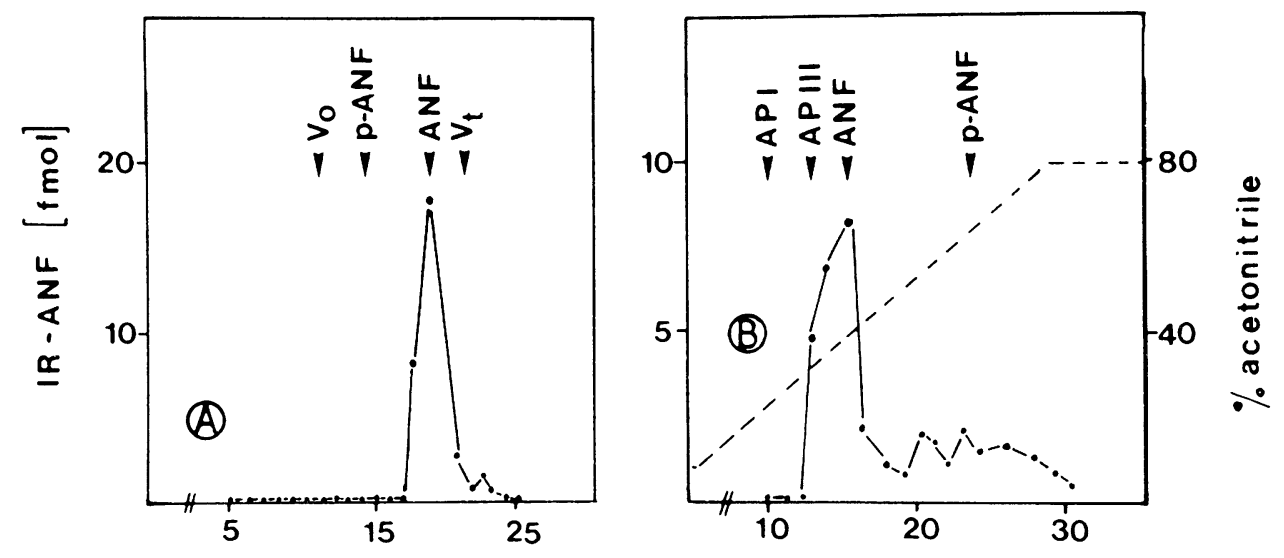

\section{fraction number}

FIG. 3

HPLC analysis of imrunoreactive ANF in ascicic fluid

A: HPGPC: The void $\left(V_{0}\right)$ and total $\left(V_{f}\right)$ volumes of the column were dectermined by $B S A$ and vitamin $B$ F2, respectively. The elution positions of synthetic rat-pro-ANF (2-126) (p-ANF) and alpha human ANF (ANF) are indicated by arrows. Fractions were tested for immunoreactive ANF by RIA.

$B$ : Reverse phase HPLC: Arrows indicate the elution positions of atriopeptin I (AP I), atriopeptin III (AP III), alpha human ANF $(A N F)$ and rat pro- ANF $(2-126)(p-A N F)$. Immunoreactive ANF was evaluated by RIA.

\section{Discussion}

This study demonstrates the presence of ANF in ascitic fluid of patients with cirrhosis of the liver. Extraction procedures as well as characteristics of our nighly sensitive and specific radioimmunoassay for deciermination of ANF in plasma have been previously described $(6,9)$. Application of the extraction procedure to aliquots of ascitic fluid yielded high recovery raies, not different from those obiained in plasma. Validity of the RIA for ANF measurement in ascites was demonsirated by parallelity of serial dilution curves with the standard curve and by the absence of significant binding interference.

In an atiempt to furtiner characterize ANF immunoreactivity in ascites, che molecular weight pattern was investigated by high performance gel permeation chromatography and reverse pinase HPLC. Whereas irace amounts of nigher molecular weight ANF in plasma of paitients with cirrnosis had been reported (9), ANF immunoreactivity in ascites coeluted with synthetic alpha numan ANF, the main circulating form in human plasma. However, due to the low concentrations of ANF in ascites and to a $48 \%$ only crossreactivity of our anitibody to pro-ANF (9), the presence of small amounts of ingier molecular weight ANF in ascites cannot be excluded. 
ANF concentrations in ascites were found to be significantly correlated to ANF plasma concentrations. This correlation as well as characterization of ascitic ANF as alpha ANF, the major circulating form of ANF, may allow the speculation that ascitic ANF is of plasma origin. ANF concentrations in ascites were found to be significantly lower than in plasina. Thus, elevations of ANF levels in plasma observed following infusion of ascitic fluid $(3,4,5)$ seem not to be due to increased levels of ANF in ascitic fluid, but ratiner due to increased release of ANF following the hemodynamic changes of infusion.

\section{Acknowledgments}

Anita Friedrich, Tobias Eisenhut, Veit Gülberg and Fabian Höpker are thanked for their support. Parts of this study were provided for by a grant from che Friedrich-Baur-Stifiung of the Faculty of Medicine, University of Munich (head: Prof. Dr. Buchborn).

\section{References}

1. A.L. GERBES, R.M. ARENDT, D. RITTER, D. JÜNGST, J. ZÄHRINGER and G. PAUMGARTNER, N. Engl. J. Med. 313 1609-1610 (1985).

2. A.L. GERBES, R.M. ARENDT and G. PAUMGARTNER, J. Hepatology $\underline{5}$ $123-132(1987)$.

3. W. BURGHARDT, H. WERNZE and K.L. DIEHL, Klin. Wochenschr. 64 (SUPP 1 VI) 103-107 (1986).

4. P. CAMPBELL, L.M. BLENDIS, K. SKORECKI, A. LOGAN, P.Y. WONG and P. GREIG, Hepatology 61120 (1986).

5. C.L. WITTE, A.P. MARTINEZ and M.H. WITTE, N. Engl. J. Med. 316 487 (1987).

6. R.M. ARENDT, E. STANGL, J. ZÄHRINGER, D.C. LIEBISCH and A. HERZ, FEBS Lett. 18957-61 (1985).

7. F. MARUMO, H. SAKAMMOTO, K. ANDO, T. ISHIGAMI and M. KAWAKAMI, Biochem. Biophys. Res. Comm. $137231-236$ (1985).

8. F. MARUMO, T. MASUDA and K. ANDO, Biochem. Biophys. Res. Comm. $143813-818(1987)$.

9. R.M. ARENDT, A.L. GERBES, D. RITTER and E. STANGL, Klin. Wochenschr. 64 (suppl VI) 97-102 (1986).

10. A.M. VOLLMAR, R.M. ARENDT and R. SCHULZ, Eur. J. Pharmacol. $143315-321(1987)$. 